\title{
FINANCIAL ALTERNATIVES TO ENABLE DISTRIBUTED MICROGENERATION PROJECTS WITH PHOTOVOLTAIC SOLAR POWER ${ }^{1}$
}

FRANCISCO IVANHOEL AGUIAR DE CARVALHO

Master's Degree in Business and Accounting Graduate Program

at the Universidade Federal do Ceará (UFC).

Regulation and Asset Control Specialist at the Enel Brasil - Companhia Energética do Ceará (Coelce).

Rua Padre Valdevino, 150, Fortaleza - CE - Brasil - CEP 60762-140

E-mail: ivanhoelc@gmail.com

\section{MÔNICA CAVALCANTI SÁ DE ABREU}

Doctor in Manufacturing Engineering from the Department of Manufacturing Engineering at the Universidade Federal de Santa Catarina (UFSC).

Associate Professor for the Department of Business

at the Universidade Federal do Ceará (UFC).

Avenida da Universidade, 2.470, Benfica, Fortaleza - CE - Brasil - CEP 60020-180

E-mail: mabreu@ufc.br

\section{JOCILDO FIGUEIREDO CORREIA NETO}

Doctor in Business Administration from the Department of Quantitative Methods and Information Technology at the Fundação Getúlio Vargas (FGV).

Professor for the Department of Business at the Universidade Federal do Ceará (UFC).

Rua Marechal Deodoro, 400, Sala 540, Benfica, Fortaleza - CE - Brasil - CEP 60020-060

E-mail: jocildo@ufc.br

Acknowledgements to the reviewers and editor for their valuable contributions with improving the initial version of this paper and to Conselho Nacional de Desenvolvimento Científico e Tecnológico (CNPq) for the financial support to the research project (\#\#401131/2010-6). 


\section{ABSTRACT}

Purpose: To explore financial alternatives to implement PV power generation projects based on the provisions of Normative Resolution n. 482/2012 of the Brazilian Electricity Regulatory Agency (Aneel). This regulation sets forth the general conditions to the access of microand minigeneration granted to the electric energy distribution systems through the energy product offset method.

Originality/gap/relevance/implications: This paper discusses the need for regulatory changes, greater government participation in the granting of financial and tax incentives so that PV solar power technology in distributed generation can be financially viable for residential consumers.

Key methodological aspects: Investment analysis in PV systems used the Net Present Value (NPV) valuation method. The research assessed two scenarios for Grid-Connected PV Systems (GCPVSs), with different solar power usage levels for a residential consumer.

Summary of key results: The results point to a low financial viability in the implementation of distributed microgeneration projects, suggesting the need to remove the tax burden and reduce financing costs.

Key considerations/conclusions: The study shows the need of flexibilization of the Brazilian regulatory model, with changes that enable the expansion of renewable energy offers, with positive economic outcomes for tariff affordability. Tariff benefits from distributed microgeneration can positively reflect on captive customers, provided that investment risks are reduced.

\section{KEYWORDS}

Distributed generation. Strategy. Photovoltaic solar system. Solar power. Investment viability. 


\section{INTRODUCTION}

From the energy security standpoint, it is imperative that countries develop new forms of generation and promote technologies that enable access to electric energy. Martins, Rüther, Pereira and Abreu (2008) establish that investments in distributed energy are presented as viable alternatives to bring electricity to populations who do not yet have access to it. Countries such as Germany, the United States, Spain, France, Italy and Japan have developed mechanisms that reduce the fossil fuel dependency with the introduction of renewable options in their primary energy supplies and decentralize power generation.

According to Pereira, Pereira, La Rovere, Barata, Villar and Pires (2011), distributed generation is understood as that located near-load small-sized centers, connected to the distribution system or in the consumer unit itself, and not dispatched by the National System Operator (ONS). In order to introduce renewable energy source mechanisms into the Brazilian energy matrix, the Brazilian Electricity Regulatory Agency (Agência Nacional de Energia Elétrica - Aneel, 2012) issued the Normative Resolution n. 482/2012, that regulates criteria for the application of distributed generation, through micro- and minigeneration.

Distributed generation in the Brazilian energy sector was implemented through an offset system in terms of consumed energy. This system, called 'net metering', consists of measuring the energy flow at a consumer unit equipped with small generation, by means of bidirectional meters. There will be reduction in consumption and the load in feeders in regions with high charge density, with loss reduction and, in some cases, postponing of investments in the expansion of distribution systems.

Rodriguez and Jannuzzi (2002) report that research on and use of distributed generation have always been more evident in off-grid projects, such as PV solar systems. The use of PV solar power has increased at annual rates of around 40\%, according to Watts, Váldés, Jara and Watson (2015). In Brazil, the solar radiation index ranges from 1,500 to $2,200 \mathrm{~kW} / \mathrm{w}^{2}$ / year, and, the State of Ceará, particularly, has a solar radiation of $18 \mathrm{MJ} / \mathrm{m}^{2}$, which is comparable to $2,008.3 \mathrm{~kW} / \mathrm{m}^{2}$ /year (Agência Nacional de Energia Elétrica, 2014).

Landau (2008) clarifies that diversification is not only a system security requirement of the system, but also it needs to include new renewable energy sources in the Brazilian energy matrix. Jannuzzi and Melo (2013) defend that the use and dissemination of PV solar power generation technology are 
viable options due to three factors: 1 . high residential tariffs; 2 . great availability of solar radiation; and 3. reduction in the price of solar modules and panels.

Based on the above, this research stems from the following problem: is the use of On-Grid PV Systems (OGPVSs), pursuant to the provisions of Aneel Normative Resolution n. 482/2012, financially viable for residential consumers of the electrical energy distribution company in the State of Ceará? This paper assesses two scenarios of investment in PV enterprises made by residential consumers and analyzes the impact of the tax burden on distributed generation.

This paper makes two contributions to the research on financial management in the energy sector. The first deals with the assessment of the impact of the tax burden and current credit lines on the installation of PV power generation technology. The second, through the analysis of barriers imposed by the current regulatory model of government incentives, identifies the efforts necessary to make PV solar power technology in distributed generation financially viable to residential consumers.

The paper is divided into sections. The conceptual aspects related to power generation capacity in Brazil and diversification opportunities are presented below. Next, the distributed generation and the offset system proposed by Aneel Normative Resolution n. 482/2012 are addressed. Then, the methodology section describes the procedures adopted in this research, and the results section presents two simulation scenarios and the prospects of investment risk reduction through government incentives. Finally, the discussion section addresses the regulatory barriers to the implementation of PV solar power and the advances necessary to insert distributed generation in the Brazilian energy matrix.

\section{CHALLENGES TO THE GENERATION AND INSERTION OF DISTRIBUTED ENERGY FROM RENEWABLE SOURCES INTO THE BRAZILIAN ENERGY MATRIX}

Since the implementation of the new sector model, which took place in 2004, the Brazilian electric sector has suffered significant financial losses. In the second semester of 2012, the Federal Government, through the Ministry of Mines and Energy, issued Provisional Presidential Decree n. 579, that was subsequently passed into Law n. 12,783/2013. These new rules changed the concession contract for generation, distribution and transmission expiring in 2017. 
Some sector burdens were extinguished, such as the Global Reversion Reserve (RGR) and the Fossil Fuel Consumption Account (CCC), and others had their share reduced, such as the Energy Development Account (CDE). With this measure, an average reduction was expected of $20.2 \%$, with a $16.2 \%$ deduction to the residential sector, and $28.0 \%$ to industries (Ministério de Minas e Energia, 2012). According to Barroso, Rosenblatt and Veiga (2015), Provisional Presidential Decree n. 579/2012 did not create the expected effects, resulting in a negative combination of (structural) operational constraints (of the energy sector) and worsened efficiency of generation plants.

In late 2012, the reduction of tariffs and the consequent increase in consumption led to the need for continuously activating the whole thermoelectric complex, even in favorable hydrological situations. In 2013, the increase in demand forced the dispatch of operation of thermoelectric plants, at a cost of $\mathrm{R} \$ 25$ billion. The combination of accelerated emptying of reservoirs with the continuous activation of thermal plants resulted in record prices in the spot market and financially strained thermal and hydroelectrical generators (Barroso et al., 2015).

In 2014 , the domestic energy demand increased by $5.3 \%$ over the previous year. The cost of energy generated by fossil sources (thermal plants) is on average 1.5 times higher than that of hydro-power sources. It was, however, the only generation matrix able to meet the availability required by the electrical system. This regulatory instability environment call for an energy plan that includes not only government incentives, but also more flexible forms of regulation in the energy purchase agreement markets. Viana, Rüther, Martins and Pereira (2011) emphasize the need for diversifying the energy matrix with renewable energy sources. Dias, Bastian-Pinto, Brandão and Gomes (2011) demonstrate the existence of a significant potential for investments in bioelectricity cogeneration (CHP), and even the renovation of older CHP units.

The regulation of Law n. 10,438/2002 (Brasil, 2002) created the Incentive Program for Alternative Energy Sources (Proinfa) from small hydro-power plants (PCHs), wind-power plants and energy generation through biomass. Some improvements necessary to the operationalization of Proinfa were introduced by Law n. 10,762/2003 (Brasil, 2003). Proinfa represents a significant advance towards diversification of the Brazilian energy matrix. Advances in Proinfa took place with the introduction of distributed generation by Aneel Normative Resolution n. 482/2012.

Consumers serviced by the program are those belonging to 'group $A$ ' (binomial tariffs) and 'group B' (monomial tariffs). Tariffs in 'group A' are for consumers serviced by the high tension, 2.3 to $230 \mathrm{kV}$ network, and 
receive designations with letters and numbers indicating the supplied voltage. On the other hand, tariffs in 'group B' are aimed at consumer units serviced in voltages below $2.3 \mathrm{kV}$. In Brazil, 'group B' tariffs are established only for the energy consumption component, in Reais per megawatt-hour $(\mathrm{R} \$ / \mathrm{MWh})$, considering that the cost of power demand is included in the cost of energy supply in megawatt-hour.

Aneel Normative Resolution n. 482/2012 created energy offset mechanisms that consist of calculating the monthly balances, considering energy consumed and produced. If the consumer produces more energy than s/he consumes, this 'exceeding' amount is entered in the distribution company's system, and can be offset in future energy bills within 36 months. Among the incentives, there is the charge of at least the amount related to the availability cost for 'group B' consumers, or of the contracted demand for 'group A' consumers.

Invoiced consumption must be the energy consumed during the month, deducting the energy inserted in the month and occasional energy surplus accumulated in previous months, per billable unit. The energy produced in 'group A' consumer units and offset in other 'group B' units must take into account the ratio between the sum of components of 'Use of the Distribution System" (TUSD) and 'Energy' (TE) tariffs, in R \$/MWh. In consumer units with hourly tariffs, offset must be made primarily in the billable unity where the generation took place, and subsequently in the other billable units where the priority order of energy surplus offset is defined by the consumer.

Rüther (2008) warns against the obstacles to the implementation of on-grid PV solar power (SFCR). It is necessary to develop a connection standard to the distribution network; to reduce the difficulty in measuring generated energy; and a better management of systems operating in parallel with the grid. The cost pass-through to the tariff, limited to a reference value, and the implementation of incentive mechanisms are not clearly defined.

In terms of incentives for PV solar power, Aneel established an $80 \%$-deduction for solar sources with inserted power below or equal to $30 \mathrm{MW}$ in distribution and transmission systems. This deduction is valid for enterprises commencing operation until 31 December 2017. Additionally, it expanded the deduction in the first ten years of plant operation, applicable over TUSD and TUST (Tarif for the Use of the Transmission System). After this period, a reduction to $50 \%$ in the deduction is provided for, which will be applied in these tariffs. However, the raise in deductions in TUSD may cause excessive impacts on the tariffs.

According to Lacchini and Santos (2013), the cost of PV power represents an amount between US\$0.58/kWh and US\$1.16/kWh. These values 
may be considered optimistic, since the PV power market is subject to variables which are difficult to control, such as: 1. the cost of the dollar, that influences the acquisition of imported equipment; 2 . price of the solar source offered in an auction; and 3. the unstable regulatory model of the energy sector, that hinders a greater technological adherence.

In Brazil, the installed capacity of PV solar generation, as of January 2015, was 15 MW (Agência Nacional de Energia Elétrica, 2015). This installed capacity represents $0.01 \%$ of the Brazilian energy matrix (Ministério de Minas e Energia, 2015). Brazil's Northeastern region has $44 \%$ of installed capacity of the Brazilian solar generation complex. In terms of solar power generation, the State of Ceará has an average of 7.5 hours of sunlight per day and global solar radiation ranging from 5.0 to $6.5 \mathrm{kWh} / \mathrm{m}^{2} /$ day (Empresa de Pesquisa Energética, 2015).

Jannuzzi and Melo (2013) report that countries are studying new renewable energy insertion policies in their energy matrices. The European Union, for instance, adopts the feed-in-tariffs methodology, which consists in interconnecting the consumers' renewable generation system to the supply network, with tariff costs subsidized for 20 years. This model is a form of government incentive to boost consumers' adherence to on-grid solar or wind power generation.

Spain has developed a program to insert clean energy in its matrix, aiming to: 1 . reduce importation of fossil fuels; 2 . increase energy use efficiency; and 3. improve environment quality, in addition to the promotion of job creation and boosting social development. In Italy, the on-grid PV systems installation program installed, until 2005, 50MWp (Lora \& Haddad, 2006).

In Brazil, there is not yet a database with reliable historical records on distributed microgeneration with PV solar power, which hinders analyses and projections by statistical or mathematical models. Thus, studies must be carried out in order to infer the financial viability of PV installations, considering the current economic, technological situation and the regulatory framework.

\section{METHODOLOGY}

The research consists of a financial evaluation on the implementation of distributed PV solar generation projects for residential clients classified as B1, located in the city of Fortaleza, and serviced by the Energy Company of State of Ceará (Coelce). Such analyses were carried out in different scenarios regarding power generation (Scenario 1 - energy self-sufficiency; and 
Scenario 2 - power generation in the time period between 08:00 a.m. and 3:00 p.m. - the "sunlight time"); taxation levels (with or without taxation); bank financing share (total or partial) and bank financing interest rates (monthly interest rates of $1.94 \%$ and $3.50 \%$ ). The combinations of all these circumstances result in 16 financial alternatives to make PV solar power distributed microgeneration projects viable.

First, data were collected and analyzed in order to support the definition of the technical structure necessary to power generation in two scenarios. In scenario 1, the consumer's aim is to become self-sufficient in relation to the consumption of the energy delivered by the distribution company. Therefore, the purpose is to generate energy so that he/she does not depend on the electric energy tariffed by the concessionaire, paying only the regulatory minimum fee. In scenario 2, the consumer's aim is to bring its energy bill to zero in the period between 08:00 a.m. and 03:00 p.m. through solar power generation.

The database of Coelce was used to collect information on electric energy consumption, invoicing, the number of residential clients, and clients with tariff subsidies, as well as the charge profile of clients invoiced in the B1 residential consumer class, whose consumption was higher than $220 \mathrm{kWh}$ per month. We identified 226,000 clients in this segment. Figure 1 shows the distribution of average consumption for this client profile throughout a complete day ( 24 hours). The results indicate an average daily consumption of $35.44 \mathrm{~kW}$ with a maximum charge of $4.08 \mathrm{~kW}$ taking place at 09:00 p.m.

\section{(Figure 1)}

AVERAGE CHARGE FLOW FROM THE CONCESSIONAIRE

TO A RESIDENTIAL CLIENT THROUGHOUT THE DAY

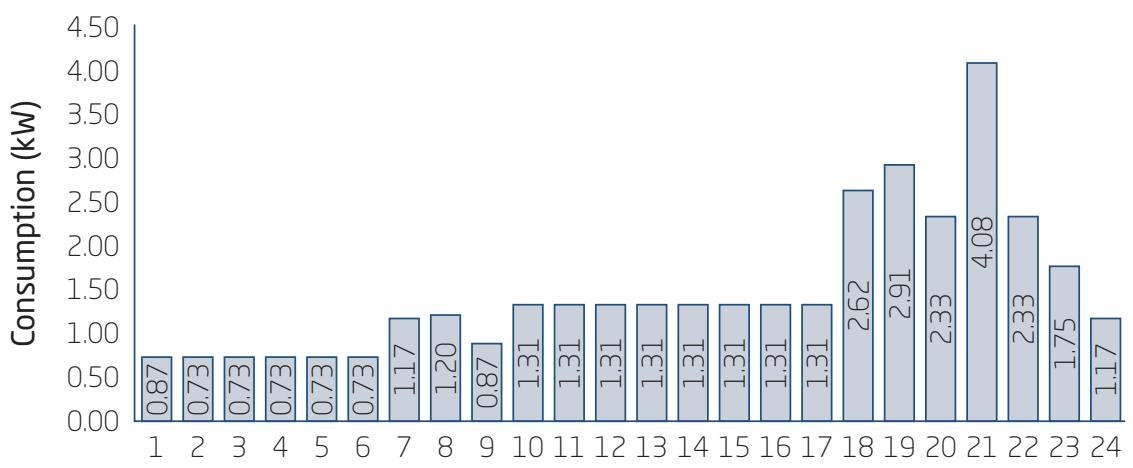

Times of the day 
In order to generate another consumption reference per B1 residential client, we also used a solar simulator from Instituto Ideal named "América do Sol". This procedure was suggested by Nascimento and Rüther (2014), who indicate that the use of this simulator can be made in a practical and quick manner. The results for the consumer profile in Coelce's B1 residential consumer class are shown in table 1 . The data calculated by the simulator indicate that the average daily consumption is $26.67 \mathrm{~kW}$ per day.

\section{(Table 1)}

DATA FROM THE "AMÉRICA DO SOL" SIMULATOR, CONSIDERING THE B1 RESIDENTIAL CONSUMER CLASS PROFILE

\begin{tabular}{ccccccc}
\hline $\begin{array}{c}\text { Household } \\
\text { Appliances }\end{array}$ & Number & Power & Hours & $\begin{array}{c}\text { Consumption } \\
\text { Wh/day }\end{array}$ & $\begin{array}{c}\text { Consumption } \\
\text { kWh/day }\end{array}$ & $\begin{array}{c}\text { Consumption } \\
\text { kWh/month }\end{array}$ \\
\hline $\begin{array}{c}\text { Indoor } \\
\text { Lighting }\end{array}$ & 10 & 18 & 2 & 360 & 0.36 & 10.80 \\
\hline $\begin{array}{c}\text { Outdoor } \\
\text { lighting }\end{array}$ & 8 & 15 & 4 & 480 & 0.48 & 14.40 \\
\hline TV & 3 & 400 & 3 & 3,600 & 3.60 & 108.00 \\
\hline Video & 1 & 300 & 1 & 300 & 0.30 & 9.00 \\
\hline Computer & 3 & 200 & 3 & 1,800 & 1.80 & 54.00 \\
\hline Fridge & 2 & 130 & 8 & 2,080 & 2.08 & 62.40 \\
\hline Washing & 1 & 800 & 1 & 800 & 0.80 & 24.00 \\
\hline machine & 2 & 1000 & 2 & 4,000 & 4.00 & 120.00 \\
\hline Clothes Iron & 2 & 182 & 2 & 727 & 0.73 & 21.80 \\
\hline Shelf Stereo & 2 & 220 & 2 & 440 & 0.44 & 13.20 \\
\hline Blender & 1 & 360 & 2 & 2,880 & 2.88 & 86.40 \\
\hline Rotating fan & 4 & 1200 & 1 & 1,200 & 1.20 & 36.00 \\
\hline Grill & 1 & 2000 & 2 & 8,000 & 8.00 & 240.00 \\
\hline Freezer & 2 & 24 & 26,667 & 26.67 & 800 \\
\hline Total & & & 50400 & & & \\
\hline
\end{tabular}

Source: América do Sol simulator, 2014.

The result calculated with the use of the "América do Sol" simulator is around $25 \%$ lower than that calculated based on Coelce's B1 consumer 
database. For simulation purposes, this study adopted the higher average consumption amount for a B1 residential client, which decreases the risk of electric energy shortage from PV solar panels.

In scenario 1, in order to make the consumer self-sufficient, the PV panel set has to generate $4.44 \mathrm{~kW}$. This amount meets the peak demand that takes place at 09:00 p.m., and was calculated considering the daily consumption (i.e., $35.44 \mathrm{~kW}$ ), divided by 8 hours of solar radiation incidence. In scenario 2, the average consumption was calculated between 08:00 a.m. and 03:00 p.m. (i.e., $9.93 \mathrm{~kW}$ ), divided by 8 hours of solar radiation incidence, resulting in $1.24 \mathrm{~kW}$.

From these data, it was possible to estimate the technical structure necessary in each power generation scenario. Thirteen types of PV panels available in the market were compared and use on-grid technology, which allows the connection to Coelce's grid. The following panel features were measured: maximum power, height, width, weight, panel performance, kind of connection, panel unit power, manufacturer's guarantee, maintenance costs, and panel cost. We chose a device manufactured by Kyocera Solar do Brasil Ltda., with panel KD140SX-UPU, which provided the best cost-benefit ratio, with a 25 -year service life, as described in Table 2.

\section{(Table 2)}

PV PANEL TECHNICAL FEATURES, COSTS AND TAXES LEVIED

\begin{tabular}{|c|c|c|}
\hline Parameters & Items evaluated & Amounts \\
\hline \multirow{6}{*}{$\begin{array}{l}\text { PV Panel } \\
\text { Technical } \\
\text { Features }\end{array}$} & Solar efficiency in Ceará & $21 \%$ \\
\hline & Maximum generation power & $3.24 \mathrm{kWh}$ \\
\hline & Type of Panel & KD140SX-UPU \\
\hline & Manufacturer & Kyocera Solar do Brasil Ltda. \\
\hline & Performance (Pot-STC/Pot-800W/m²) & $72.14 \%$ \\
\hline & Panel Unit Power & $140 W$ \\
\hline \multirow{5}{*}{ Cost in $\mathrm{R} \$$} & Panel Unit Cost & 853.00 \\
\hline & Inverter Cost & 2,999.56 \\
\hline & Installation Costs - Scenario 1 & $1,857.39$ \\
\hline & Installation Costs - Scenario 2 & 533.83 \\
\hline & Maintenance Service Sign-up Cost & 200.00 \\
\hline
\end{tabular}




\section{(Table 2 (Conclusion))}

PV PANEL TECHNICAL FEATURES, COSTS AND TAXES LEVIED

\begin{tabular}{ccc}
\hline Parameters & Items evaluated & Amounts \\
\hline & Cofins - Regular Invoice & 3.82 \\
\cline { 2 - 3 } Taxes (\%) & PIS - Regular Invoice & 0.83 \\
\cline { 2 - 3 } & ICMS - Regular Invoice & 27.00 \\
\cline { 2 - 3 } & PIS - Distributed Generation. & 1.65 \\
\hline Cofins - Distributed Generation & 7.60 \\
\hline ICMS - Distributed Generation & 27.00 \\
\hline
\end{tabular}

Source: Sun Solutions (2014); Ceará (2017).

In scenario 1 (energy self-sufficiency), the power generated by the PV system must be $4.44 \mathrm{~kW}$. Since each PV panel has a $140 \mathrm{~W}$ power, therefore, 32 panels and three inverters are necessary. In scenario 2 , the total size of the PV panel to be used took into account the ratio between the total useful generation expectation $(1.24 \mathrm{~kW})$, for an effect during "sunlight time", divided by the generation power in each PV panel (140 W). Therefore, nine panels and one inverter are necessary. Table 3 sums up the investment amounts in scenarios 1 and 2 , in both taxed and untaxed situations.

\section{(Table 3)}

INVESTMENT AMOUNTS IN SCENARIOS 1 AND 2 FOR POWER GENERATION AND TAXATION/TAX EXEMPTION

\begin{tabular}{|c|c|c|c|c|}
\hline \multirow[t]{2}{*}{ Investment items } & \multicolumn{2}{|c|}{$\begin{array}{l}\text { Scenario } 1 \text { - energy } \\
\text { self-sufficient ( } R \$ \text { ) }\end{array}$} & \multicolumn{2}{|c|}{$\begin{array}{l}\text { Scenario } 2 \text { - Power } \\
\text { generation during } \\
\text { sunlight time (R\$) }\end{array}$} \\
\hline & With taxes & $\begin{array}{l}\text { Without } \\
\text { taxes }\end{array}$ & With taxes & $\begin{array}{l}\text { Without } \\
\text { taxes }\end{array}$ \\
\hline Panels & $27,296.00$ & $18,656.82$ & $7,677.00$ & $5,247.23$ \\
\hline Inverters & 8,998.68 & $6,150.60$ & 2,999.56 & $2,050.20$ \\
\hline Total Installation Cost & $1,814.73$ & $1,240.37$ & 533.83 & 364.87 \\
\hline $\begin{array}{l}\text { Maintenance Service Sign-up Cost } \\
\text { (as per manufacturer information) }\end{array}$ & 200.00 & 200.00 & 200.00 & 200.00 \\
\hline Total & $\mathrm{R} \$ 38,309.41$ & $R \$ 26,247.78$ & $R \$ 11,410.39$ & $R \$ 7,862.30$ \\
\hline
\end{tabular}

Source: Prepared based on quotations requested from manufacturer 
With the technical structure defined, two estimates were made regarding the expected savings. A key aspect involves the financing timeframe. The PV solar power equipment technical information indicate that its service life is 25 years. Leonelli, Galdino, Pereira, Rüther and Zilles (2009) also suggest this 25-year financing time frame, in the PV Systems Distributed Generation Work Group Report (GT-GDSF), submitted to the Ministry of Mines and Energy.

In order to estimate the expected savings, we carried out a projection of cash flows from the client unit's energy consumption and generation provided in relation to the investment made, as per the guidelines imposed by Aneel Normative Resolution n. 482/2012. It is worth noting that, regarding the measurement of the model suitability, the simulation calculation formatting received critical analyses of Coelce's invoicing and engineering areas (technical projects). The regulation area and company's market were also consulted, so that the simulations are in accordance with the legal provisions set forth by Aneel.

The energy consumed consists of the monetary value of consumer's invoice related to the energy delivered by the distribution company to its captive clients. This calculation is obtained through the product between the tariff authorized by Aneel and the energy made available by the grid. Besides this item, there is the public street lighting charge, which follows a table based on the consumer unit's consumption profile. This cost does not belong to the distribution company, but consumers have to consider it in their cash flow, because it is shown in their electric power bill. The concessionaire collects this tariff from all consumers and passes it on to the municipal administration.

Distributed power generation, which represents the monetary value of energy per distributed generation, will be deducted from total consumption. This amount is obtained through the product between the tariff authorized by Aneel and the power generated by the PV solar system. One aspect that influences the calculation of distributed power generation is the equipment efficiency level, which determines the efficiency of PV installations throughout the equipment's 25-year service life. According to the manufacturer's determination, around $5 \%$ of efficiency is lost every 5 years and this calculation was measured for the economic flow.

The savings achieved are obtained by the incremental cash flow between how much would be paid in a non-solar power situation and how much would be paid in a solar power situation (Correia, 2009). As for the tariff considered in the financial viability assessments, we used the one authorized by Aneel in the 2013 tariff adjustment, which is in effect for one year, and is $\mathrm{R} \$ 0.35922 / \mathrm{kWh}$. With the addition of due taxes (ICMS, PIS and 
Cofins), the final tariff value is at $\mathrm{R} \$ 0.52556 / \mathrm{kWh}$. This tariff also considers the tariff flags methodology, adopting the red tariff flag.

As for the project's financing, some possibilities were considered based on consultancies carried out in commercial banks which have financing lines for renewable energy projects aimed at individuals. Caixa Econômica Federal (a Brazilian public banks), for instance, offers financing though its credit mode called "Construcard", to which the client may have access to interest rates ranging from $1.96 \%$ to $2.35 \%$ per month. Banco do Brasil (another Brazilian public bank), in turn, also offers this financing credit line through 'BB Crédito Material Construção' (a construction credit line) and applies interest rates ranging from $1.94 \%$ to $3.5 \%$ per month, and a maximum amortization deadline of five years.

Therefore, we decided that the projects could be either totally or partially financed ( $80 \%$ of the invested amount) by using the credit line offered by Banco do Brasil, at the higher financing cost of $3.5 \%$, and at the smaller cost of $1.94 \%$. For these monthly interest rates, we analyzed both scenario 1 (energy self-sufficiency) and scenario 2 (time period between 08:00 a.m. and 03:00 p.m. ("sunlight time"). As for taxes, we adopted two situations. An integral taxation on all the elements of the project (investments, energy consumption and generation) and other allowing tax exemption for all these elements.

Cash flow was projected with current prices, including inflation. Instead of adopting a generic inflation index, the projected cash flow adopted the average amount of the Tariff Adjustment Index (IRT) from 2008-2012. This readjustment follows the methodology defined by Aneel (Authorizing Resolutions n. 641/2008; n. 807/2009; n. 968/2010; n. 1277/2012; n. 1516/2013) in order to keep the economic and financial balance of the granting contract.

For the appraisal of IRT, Aneel defines the revenue by means of two parts (A and B). Part A considers the reference market and conditions in effect as of the periodic tariff adjustment. In addition to sector charges, this part includes electric energy acquisition costs and costs with connection and use of the distribution and/or transmission system.

Part B encompasses proper costs of activities of distribution and client commercial management, which depends on the management model adopted by the concessionaire. This part includes operation and maintenance expenses, the regulatory re-integration quota, capital remuneration and annual cost of both moveable and immovable installations. The Inflation Variation Index (IGP-M), published by Fundação Getúlio Vargas, is precisely applied to part B. For the 2008-2012 period, the average value of IRT was $9.14 \%$ per year, and it was used to readjust the projected cash flow accounts. This rate was applied to the tariffs making up the cash flow every 12 months. 
The viability assessment of projects used the following methods: Net Present Value (NPV), Internal Return Rate (IRR) and Deducted Payback Period (DPBP). According to Casarotto and Kopittke (2007), NPV translates the best ratio between involved costs and expected revenues, when compared to the minimum acceptable rate of return (MARR). If NPV is positive, this means that disbursements are compensated for by the positive cash flows generated, indicating the project's viability. Otherwise, if NPV is negative, the project is inviable, because disbursements are not financially compensated for.

IRR is a percentage index of the project's attractiveness. It represents the project's return in percentage points. The decision criterion is to compare IRR to MARR. If IRR is greater than MARR, that means the project's percentage return is higher than the minimally attractive considered return, which suggests the project is financially viable. Otherwise, the project is not viable. DPBP is an indicator of the capital budget whose purpose is to indicate the period of time necessary to return the investment made. Therefore, the shorter the payback period is, more interesting the project will be. If the payback period is not achieved during the time frame analysis, the project is not viable.

In all methods, as stated by Casarotto and Kopittke (2007), a MARR must be adopted. It corresponds to the rate adjusted to the risk of operation and from which the investment pays the owner, that is, the investor makes financial gains on the amount invested. The monthly MARR adopted for this study was $1.50 \%$ per month. This rate considers the minimum monthly gain for an (individual) investor, so that it exceeds the other, traditional investment alternative, such as a fixed income investment. This is a conservative percentage, considering residential clients' economic condition and aversion to financial risk.

\section{RESULTS}

\subsection{Financial assessments for scenario 1 (energy self-sufficiency)}

The total cost of installation of PV panels in scenario 1 was $\mathrm{R} \$ 38,309.41$. In the $80 \%$ financing case, the amount goes down to $\mathrm{R} \$ 30,647.53$. A simulation was carried out following the premises defined by Aneel Normative Resolution n. 482/2012, with a 3.5\% interest rate. In scenario 1 (energy self-sufficiency), the enterprise's cash flow did not show a favorable NPV. In another simulation, considering the reduction in bank financing cost to 
$1.94 \%$, we have a NPV close to zero, and deducted payback periods are well close to 25 years, as shown in table 4 .

\section{(Table 4)}

FINANCIAL ASSESSMENTS FOR SCENARIO 1 FOR FULL AND PARTIAL FINANCING, CONSIDERING THE PROVISIONS OF ANEEL NORMATIVE RESOLUTION N. 482/2012 AND TAX BURDEN REMOVAL, WITH 3.5\% AND 1.94\% FINANCING COSTS

\begin{tabular}{|c|c|c|c|c|c|}
\hline \multirow{3}{*}{$\begin{array}{l}\text { Financing } \\
\text { features }\end{array}$} & \multirow{3}{*}{ Decision Items } & \multicolumn{4}{|c|}{ Scenario 1 - energy self-sufficiency } \\
\hline & & \multicolumn{2}{|c|}{$\begin{array}{l}\text { Normative resolution } \\
482 / 2012\end{array}$} & \multicolumn{2}{|c|}{ Tax burden removal } \\
\hline & & $\begin{array}{c}\text { Higher } \\
\text { investment } \\
\text { cost }(3.5 \%)\end{array}$ & $\begin{array}{c}\text { Lower } \\
\text { investment } \\
\text { cost }(1.94 \%)\end{array}$ & $\begin{array}{c}\text { Higher } \\
\text { financing cost } \\
(3.5 \%)\end{array}$ & $\begin{array}{c}\text { Lower } \\
\text { financing cost } \\
(1.94 \%)\end{array}$ \\
\hline \multirow{6}{*}{ Full } & Financed Amount & $R \$ 38,309.41$ & $R \$ 38,309.41$ & $R \$ 26,247.78$ & $R \$ 26,247.78$ \\
\hline & Down payment & $R \$ 0.00$ & $R \$ 0.00$ & $R \$ 0.00$ & $R \$ 0.00$ \\
\hline & Installment & $\mathrm{R} \$ 1,439.18$ & $R \$ 957.02$ & $R \$ 986.06$ & $R \$ 655.70$ \\
\hline & NPV & $-R \$ 21,302.51$ & $R \$ 777.99$ & $\mathrm{R} \$ 184.18$ & $R \$ 15,312.68$ \\
\hline & IRR & $0.98 \%$ & $1.53 \%$ & $1.51 \%$ & $2.41 \%$ \\
\hline & DPBP (years) & - & 23.25 & 24.67 & 9.92 \\
\hline \multirow{6}{*}{$\begin{array}{l}\text { Partial } \\
\text { (80\%) }\end{array}$} & Financed Amount & $R \$ 30,647.53$ & $\mathrm{R} \$ 30,647.53$ & $R \$ 20,998.23$ & $R \$ 20,998.23$ \\
\hline & Down payment & $R \$ 7,661.88$ & $R \$ 7,661.88$ & $R \$ 5,249.56$ & $R \$ 5,249.56$ \\
\hline & Installment & $\mathrm{R} \$ 1,151.34$ & $R \$ 765.61$ & $R \$ 788.84$ & $R \$ 524.56$ \\
\hline & NPV & $-R \$ 15,782.97$ & $\mathrm{R} \$ 1,881.43$ & $R \$ 3,965.90$ & $R \$ 16,068.71$ \\
\hline & IRR & $1.10 \%$ & $1.57 \%$ & $1.64 \%$ & $2.34 \%$ \\
\hline & DPBP (years) & - & 21.08 & 18.75 & 9.50 \\
\hline
\end{tabular}

Source: Elaborated by the authors.

The removal of tax burden reduces the total effective installation cost of PV panels in scenario 1 to $\mathrm{R} \$ 26,247.78$ in the case of full financing, and to $\mathrm{R} \$ 20,998.23$ in partial financing. The financial assessments carried out considering the higher, $3.5 \%$ interest rates show a greater investment attractiveness for the $80 \%$ partial financing condition, when compared to full financing. However, the investment payback period keeps long, around 19 and 25 years, respectively. 
Maintaining the removal of tax burden and reducing financing cost to a $1.94 \%$ interest rate, we can notice a significant improvement in the investment attractiveness for scenario 1 . The financial assessment results show that tax exemption associated to a reduce interest rate brought the payback period down to about 10 years in both financial cases (full and partial).

\subsection{Financial assessments for scenario 2 (power generation during sunlight time)}

The disbursements needed for the investment in scenario 2, in which power generation considers the period of time between 08:00 a.m. and 03:00 p.m., the "sunlight time", total R\$11,410.39. In the case of partial financing, the amount is $\mathrm{R} \$ 9,128.31$. Considering the provisions of Aneel Normative Resolution n. 482/2012 and the financing conditions, with a $3.5 \%$ interest rate, the investment cash flow does not present a favorable NPV. In table 5 , we can see that investments for scenario 2 continue not being attractive, even if we consider the lower, $1.94 \%$ interest rate.

\section{(Table 5)}

FINANCIAL ASSESSMENTS FOR SCENARIO 2 FOR FULL AND PARTIAL FINANCING, CONSIDERING THE PROVISIONS OF ANEEL NORMATIVE RESOLUTION N. 482/2012 AND TAX BURDEN REMOVAL, WITH 3.5\% AND $1.94 \%$ FINANCING COSTS

\begin{tabular}{|c|c|c|c|c|c|}
\hline \multirow{3}{*}{$\begin{array}{l}\text { Financing } \\
\text { features }\end{array}$} & \multirow{3}{*}{ Decision Items } & \multicolumn{4}{|c|}{ Scenario 2 - Power generation during sunlight time } \\
\hline & & \multicolumn{2}{|c|}{$\begin{array}{c}\text { Normative Resolution } \\
\text { n. 482/2012 }\end{array}$} & \multicolumn{2}{|c|}{ Tax burden removal } \\
\hline & & $\begin{array}{c}\text { Higher } \\
\text { investment } \\
\text { cost }(3.5 \%)\end{array}$ & $\begin{array}{c}\text { Lower } \\
\text { investment } \\
\text { cost }(1.94 \%)\end{array}$ & $\begin{array}{c}\text { Higher } \\
\text { investment } \\
\text { cost }(3.5 \%)\end{array}$ & $\begin{array}{c}\text { Lower } \\
\text { investment } \\
\text { cost }(1.94 \%)\end{array}$ \\
\hline \multirow{6}{*}{ Full } & Financed Amount & $\mathrm{R} \$ 11.410,39$ & $R \$ 11.410,39$ & $\mathrm{R} \$ 7.862,30$ & $\mathrm{R} \$ 7.862,30$ \\
\hline & Down payment & $R \$ 0,00$ & $R \$ 0,00$ & $R \$ 0,00$ & $R \$ 0,00$ \\
\hline & Installment & $R \$ 428,66$ & $R \$ 285,05$ & $R \$ 295,36$ & $R \$ 196,41$ \\
\hline & NPV & $-R \$ 7.085,27$ & $-R \$ 508,63$ & $R \$ 6.152,29$ & $R \$ 10.683,90$ \\
\hline & IRR & $0,91 \%$ & $1,44 \%$ & $2,39 \%$ & $8,79 \%$ \\
\hline & DPBP (years) & - & - & 9,92 & 2,33 \\
\hline
\end{tabular}




\section{(Table 5 (Conclusion))}

FINANCIAL ASSESSMENTS FOR SCENARIO 2 FOR FULL AND PARTIAL FINANCING, CONSIDERING THE PROVISIONS OF ANEEL NORMATIVE RESOLUTION N. 482/2012 AND TAX BURDEN REMOVAL, WITH 3.5\%

\section{AND $1.94 \%$ FINANCING COSTS}

\begin{tabular}{|c|c|c|c|c|c|}
\hline \multirow{3}{*}{$\begin{array}{l}\text { Financing } \\
\text { features }\end{array}$} & \multirow{3}{*}{ Decision Items } & \multicolumn{4}{|c|}{ Scenario 2 - Power generation during sunlight time } \\
\hline & & \multicolumn{2}{|c|}{$\begin{array}{c}\text { Normative Resolution } \\
\text { n. } 482 / 2012\end{array}$} & \multicolumn{2}{|c|}{ Tax burden removal } \\
\hline & & $\begin{array}{c}\text { Higher } \\
\text { investment } \\
\text { cost }(3.5 \%)\end{array}$ & $\begin{array}{c}\text { Lower } \\
\text { investment } \\
\text { cost }(1.94 \%)\end{array}$ & $\begin{array}{c}\text { Higher } \\
\text { investment } \\
\text { cost }(3.5 \%)\end{array}$ & $\begin{array}{c}\text { Lower } \\
\text { investment } \\
\text { cost }(1.94 \%)\end{array}$ \\
\hline \multirow{6}{*}{$\begin{array}{l}\text { Partial } \\
(80 \%)\end{array}$} & Financed Amount & R\$ 9.128,31 & R\$ 9.128,31 & $R \$ 6.289,84$ & $R \$ 6.289,84$ \\
\hline & Down payment & $R \$ 2.282,08$ & $R \$ 2.282,08$ & $R \$ 1.572,46$ & $R \$ 1.572,46$ \\
\hline & Installment & $\mathrm{R} \$ 342,93$ & $\mathrm{R} \$ 228,04$ & $R \$ 236,29$ & $\mathrm{R} \$ 157,13$ \\
\hline & NPV & $-R \$ 5.441,28$ & $-R \$ 179,97$ & $R \$ 7.285,07$ & $R \$ 10.910,36$ \\
\hline & IRR & $1,03 \%$ & $1,48 \%$ & $2,56 \%$ & $4,15 \%$ \\
\hline & DPBP (years) & - & - & 8,58 & 3,67 \\
\hline
\end{tabular}

Source: Elaborated by the authors.

The removal of tax burden represents a reduction in the financed amount to $\mathrm{R} \$ 7,862.30$ in the case of full financing, and to $\mathrm{R} \$ 6,289.84$ in the case of the $80 \%$ partial financing. We can notice a significant improvement in NPV and reduction in the payback period to approximately nine years in the case of partial financing with a $3.5 \%$ interest rate. The results confirm the impact of tax burden removal in the acquisition of equipment in B1 residential class clients' investment decisions, even in a higher financing cost condition.

Maintaining the removal of tax burden and reducing financing cost to a $1.94 \%$ interest rate, we can notice a significant improvement in the investment attractiveness for scenario 2, with raised NPV values and a payback period of only 2.33 years in the full financing condition, and 3.67 years in partial financing.

In principle, we could expect full financing to show a higher DPBP than that for partial financing. This result probably occurs because of the positive effect of financial leverage. The financing capital cost $(1.94 \%)$ is lower that the cash flow IRR with full financing $(8.79 \%)$, and the IRR with partial financing $(4.15 \%)$, and the balance is less expressive in relation to the latter. 
In addition, NPVs are very close to each other, as well as the periodic incremental cash flows. Finally, in full financing, effectively, consumer does not have any initial disbursement for equipment acquisition, whereas, in partial financing, there is an immediate disbursement.

The results shown for scenarios 1 and 2 confirm the government's role in the creation of a set of positive circumstances, such as tax burden removal and reduction of financing costs. These conditions create a favorable environment so that $\mathrm{B} 1$ residential class consumers can choose to invest in $\mathrm{PV}$ solar power distributed microgeneration projects.

\section{DISCUSSION}

The study confirms that the use of on-grid PV Systems, according to the provisions of Aneel Normative Resolution n. 482/2012, is not financially viable for Coelce's residential consumers. There is, therefore, the need to expand economic and government incentives in order to guarantee the insertion of this technology into the Brazilian energy matrix. The adoption of incentive public policies depends on a stable political and regulatory environment, with coherent rules that may make the investment in renewable sources attractive to residential consumers (small generators).

In an energy generation scenario for total offset of energy injected with minimum regulatory payment (scenario 1), the savings measured in the power bill would not be enough to guarantee the expected return for the amount invested. The best result was found with the removal of tariffs and a $1.94 \%$ financing cost, in which we had a payback period of 9.5 years. In the case of scenario 2 , power generation in order to bring the power bill to zero in the period between 08:00 a.m. and 03:00 p.m., we verified that there is a benefit to consumers, since the invoice to be paid and the investment return period are reduced. Tax exemption and the lower, $1.94 \%$ interest rate result in a significant reduction in the investment return period to 2.33 years, considering full financing.

A possible explanation for the impact of reducing the financing cost and tax burden in distributed microgeneration investments can be the climate and economic conditions of consumers in each state. According to Holdermann, Kissel and Beigel (2014), a 20\%-cut in financing costs could result, on average, in a $6 \%$ to $10 \%$ increase in the rate of adherence to the implementation of PV systems. In Brazil, investment costs in the acquisition of PV equipment are, on average, $32.5 \%$ higher than in other countries. The 
reason is the incidence of taxes such as IPI (when applicable), ICMS, PIS, and Cofins.

The results of this study are coherent with those found in Aneel Technical Note n. 017/2015-SRD, that aims to change distributed generation procedures. Considering the characteristics of concession to each power distribution company, the payback was variable, since the residential-class tariff applied also differs from one company to another. The higher the tariff applied by the power distribution company, the more attractive is the investment in microgeneration. In the Ampla's concession area (Rio de Janeiro), the payback estimated for the investment in PV power generation in 2014 is 10 years, whereas, for Eletropaulo (São Paulo) consumers, the period is almost 22 years. In the case of Coelce, the payback period was measured at 13.2 years. For a 10 -year payback period, only $5 \%$ of the potential market would be willing to make such an investment.

The electric energy injected by microgenerators is, in fact, a free loan, and is later offset by the consumption in this same consumer unit or in another consumer unit belonging to the same owner, where the credits were generated. Aneel limited the reach of the energy offset system to consumers with the same Individual/Corporate Taxpayer Identification Number. However, such change does not have any practical effects, since the National Finance Policy Council (Confaz) approved the Agreement n. 006, on April $5^{\text {th }}, 2013$, establishing that ICMS tax is levied on all the energy consumed in the month, regardless of energy offset (Brasil, 2013).

Ganim (2009) asserts that most Brazilian states does not bear tax internal electric energy operations intended for commercialization. The exception to this condition is in the States of Amazonas and Ceará, where tax electric energy operations are carried out between generation and distribution units. The energy produced and consumed in the same household, for example, will not be taxed; however, if the energy offset mechanism is used in the same or in another consumer unit, these amounts of energy will be taxed.

\subsection{Public policies and corporate strategy recommendations}

Table 6 summarizes some measures that can be taken to make investments in PV solar power distributed microgeneration more attractive and competitive. The results of simulations in scenarios 1 and 2 reinforce the need for Aneel to revise Aneel Normative Resolution n. 482/2012, in order to create governmental subsidies and incentivize pro-active strategies. 


\section{(Table 6)}

\section{PUBLIC POLICIES AND CORPORATE STRATEGY RECOMMENDATIONS}

\begin{tabular}{|c|c|}
\hline Elements & Recommendations \\
\hline \multirow{4}{*}{ Public Policies } & $\begin{array}{l}\text { Apply taxation only on the difference, if positive, between final consumption } \\
\text { amounts and injected energy surplus (generation). }\end{array}$ \\
\hline & $\begin{array}{l}\text { Allow residential clients to "sell" the energy surplus in either the regulated } \\
\text { or free contracting market. }\end{array}$ \\
\hline & $\begin{array}{l}\text { Make important basic regulations of the Brazilian energy sector, such as Decree } \\
\text { n. 5,163/2004, more flexible. }\end{array}$ \\
\hline & $\begin{array}{l}\text { Adopt fee-in tariffs in which consumers subsidize the development } \\
\text { of technology to generate solar power. }\end{array}$ \\
\hline \multirow{3}{*}{$\begin{array}{l}\text { Corporate } \\
\text { Strategies }\end{array}$} & Adopt premium tariffs for feeding the grid with renewable energy sources \\
\hline & $\begin{array}{l}\text { Adopt net metering systems to guarantee the reduction of risk (charge } \\
\text { distributed on the grid), as a way of incentivizing distribution companies } \\
\text { to take part in this process and not causing losses in their service to } \\
\text { the regulated market. }\end{array}$ \\
\hline & $\begin{array}{l}\text { Allow consumers to receive reduced tariffs, that are in turn used to repay } \\
\text { the investment made. }\end{array}$ \\
\hline
\end{tabular}

Source: Elaborated by the authors.

Tariff impact is one of the key items that may either boost or slow down the advances in the use of PV solar technology in Brazilian households. We recommend that taxation be applied only on the difference, if positive, between final consumption amounts and injected energy surplus (generation). For the cases in which this difference is lower than the minimum consumption, the tax calculation basis must be the value of the availability cost of the distribution company's system (Agência Nacional de Energia Elétrica, 2016). Confaz, after meeting with Aneel, decided to propose a new agreement that authorizes states to grant tax exemptions to internal operations related to electric energy circulation, subject to invoicing under the energy offset system. Such measure still needs to be ratified by each state, and there are no guarantees of full effectiveness all over Brazil (Agência Nacional de Energia Elétrica, 2015, p. 4).

Another aspect involves the possibility of residential clients "selling" the energy surplus in the regulated contracting market. This measure implies not using the energy offset methodology. The possibility that net metering systems are adopted should guarantee the risk reduction (charge distributed 
on the grid), as a way of incentivizing distribution companies to take part in this process and not causing losses in their service to the regulated market.

It is worth considering a regulatory concept involving the tariff issue, named "Reference Value" (RV). In the event that this energy can be "sold", whether in the regulated contracting market (depending on regulatory change) or in the Free Contracting Market (ACL), the cash flow value of residential consumers who invested in PV installations is significantly changed. This generation cost will be valued on the basis of a reference value and must be considered in the investment payback. For the energy distribution companies, this RV is the pass-through threshold to tariffs to end-consumers of energy purchased of up to $105 \%$ of the regulated market, when participating in electrical energy auctions.

However, this same RV, per se, limits the contracted price of energy coming from alternative sources in the public bid methodology, which causes losses for both distribution companies and small generators. The RV is considered low to make alternative sources viable, since it is calculated by using the A-3 and A-5 auction mechanisms, in which only large hydro- and thermal plants participate. Currently, the participation in energy purchase through public bids does not foster the expansion of distributed generation. Changes in the RV calculation or the adoption of parameters for the viability of a feed-in tariff, however, will require the flexibilization of important basic regulations in the Brazilian energy sector, such as Decree n. 5,163/2004.

Corroborating the findings of this research, between 2014 and 2015, Aneel carried out simulations to assess the effects of the implementation of Normative Resolution n. 482/2012, and to measure the economic impacts on the market. As for tariff impact, the viability study put forth in this paper is in line with two scenarios proposed by Aneel. In one of these scenarios, Aneel would allow consumer units gathered by common interests to actually participate in the electric energy offset system. In the other scenario, Aneel would not only allow their participation in the energy offset system, but also remove the limitation on the power installed in the microgenerator to the charge installed in the group B consumer unit.

The results found by Aneel indicate that distribution companies can present a revenue decrease over the course of the simulated cash flow period, which was from 2015 to 2024 . However, if there is an expansion of distributed generation technology in the residential market, the cost-benefit ratio would improve as the number of consumers and the microgeneration installed power would increase. Within a 10-year timeframe, if the growth is twice as big as predicted, the residential consumer tariff would be impacted by up to $3.6 \%$, the lowest tariff impact rate when compared to the other scenarios. 
This percentage reflects a reduction in energy purchase agreements required by distribution companies, when compared to the amount of energy necessary to meet $100 \%$ of the captive market. Additionally, the changes put forth by this study for scenarios 1 and 2 are coherent with the experience currently taking place in other countries. For example, Jannuzzi and Melo (2013) identified government incentives in the US for residential clients who choose to install PV panels in their households. Consumers receive lower tariffs, which are, in turn, used to repay the investment made. A similar process also takes place in Belgium and France. In France, the incentive to solar generation takes place in two ways: premium-tariffs and income tax deductions, which amounts to $25 \%$ of the total amount invested in PV systems, with a cap established at $€ 8,000$ per taxpayer, according to the description in EPE Technical Note n. 20/212.

Gidens (2010) and Rubert, Schwardt and Abreu (2014) point out that Germany has become a worldwide reference regarding the use of renewable energy sources, due to the change in their tariff system. German regulation started adopting premium tariffs for feeding the grid with renewable energy sources in the 1990s. As for feed-in tariffs, consumers with systems connected to the supply grid must subsidize the development of technology for solar or wind power generation for 20 years.

\section{FINAL CONSIDERATIONS}

The study identified the need of improvements in Aneel Normative Resolution n. 482/2012. In conjunction with the maturation of this regulatory framework, government incentives for tax exemptions and other more attractive and affordable financing lines may be beneficial to promote the development of distributed generation through PV solar systems.

These measures would make the investment more feasible and attractive, reinforcing the thesis that better financing conditions and government subsidies are important to boost the distributed generation methodology. Tariff impact is one of the key items that may either boost or slow down the advances in the use of PV solar technology in Brazilian households.

This study, however, brings some limitations. Firstly, the financial viability assessment only reflects the economic condition in the State of Ceará and cannot be generalized to other Brazilian states. Secondly, the study did not consider country's macro-economic variables. Despite these limitations, the study shows the need of flexibilization from the Brazilian regulatory 
model with changes that allow the expansion of renewable energy offers, with positive economic outcomes for tariff affordability.

Investments in distributed microgeneration projects with PV solar power will allow residential consumers to take up strategic attitudes and contribute to the country's energy security, in a moment when the energy sector players and the regulatory agency itself are discussing flexibility and stability in the regulatory model.

\section{ALTERNATIVAS FINANCEIRAS PARA VIABILIZAR PROJETOS DE MICROGERAÇÃO DISTRIBUÍDA COM ENERGIA SOLAR FOTOVOLTAICA}

\section{RESUMO}

Objetivo: Explorar alternativas financeiras para implantar projetos de geração de energia fotovoltaica tomando por base a determinação da Resolução Normativa n. 482/2012 da Agência Nacional de Energia Elétrica (Aneel). Esta norma estabelece as condições gerais para o acesso de microgeração e minigeração conferidas aos sistemas de distribuição de energia elétrica por meio do método de compensação do produto energético.

Originalidade/lacuna/relevância/implicações: O trabalho discute a necessidade de modificações regulatórias, maior participação governamental na concessão de incentivos financeiros e tributárias, além da criação de linhas especiais de financiamento para que a tecnologia de energia solar fotovoltaica em geração distribuída seja financeiramente viável para os consumidores residenciais.

Principais aspectos metodológicos: A análise de investimento em sistemas fotovoltaicos utilizou o método de valoração pelo Valor Presente Líquido (VPL). A pesquisa avaliou dois cenários de Sistemas Fotovoltaicos Conectados à Rede (SFCR), com diferentes níveis de utilização da energia solar por um consumidor residencial.

Síntese dos principais resultados: Os resultados indicam baixa viabilidade financeira na implantação de projetos de microgeração distribuída, sugerindo a necessidade de exclusão da carga tributária e a redução dos custos de financiamento. 
Principais considerações/conclusões: O estudo demonstra a necessidade de flexibilização do modelo regulatório do Brasil, com modificações que possibilitem a expansão da oferta de energias renováveis, com efeitos econômicos positivos para a modicidade tarifária. Os benefícios tarifários oriundos da microgeração distribuída podem refletir de forma positiva para o consumidor cativo, desde que os riscos de investimentos sejam reduzidos.

\section{PALAVRAS-CHAVE}

Geração distribuída. Estratégia. Sistema solar fotovoltaico. Energia solar. Viabilidade de investimento.

\section{ALTERNATIVAS FINANCIERAS QUE PERMITAN PROYECTOS DE MICROGENERACIÓN DISTRIBUIDOS CON ENERGÍA SOLAR FOTOVOLTAICA}

\section{RESUMEN}

Objetivo: Explorar alternativas financieras para la ejecución de proyectos de construcción de la generación de energía fotovoltaica en la determinación de la Resolución n. 482/2012 reglas de Agencia Nacional de Energía Eléctrica (Aneel). Esta norma establece las condiciones generales para el acceso de micro-generación y minigeneración concedida a los sistemas de distribución de energía eléctrica por medio del método de compensación de producto energético.

Originalidad/laguna/relevancia/implicaciones: El artículo aborda la necesidad de cambios normativos, el aumento de la participación del gobierno en la provisión de incentivos financieros, fiscales y la creación de líneas de crédito especiales para la tecnología de energía solar fotovoltaica en la generación distribuida es financieramente viable para los consumidores residenciales.

Principales aspectos metodológicos: El análisis de la inversión en los sistemas fotovoltaicos utilizó el método de cálculo de Valor Actual Neto (VAN). El estudio evaluó dos escenarios de Sistemas Fotovoltaicos Conectados a la Red (SFCR), con diferentes niveles de uso de la energía solar para un cliente residencial. 
Síntesis de los principales resultados: Los resultados indican baja viabilidad en la ejecución de proyectos de microgeneración distribuida, lo que sugiere la necesidad de que la exclusión de la carga fiscal y la reducción de los costes de financiación.

Principales consideraciones/conclusiones: El estudio demuestra la necesidad de aliviar el modelo regulatorio en Brasil, con modificaciones con el fin de ampliar la oferta de energía renovable, con efectos económicos positivos para las tarifas bajas. Beneficios arancelarios de la microgeneración distribuida pueden reflejar positivamente a los consumidores cautivos, ya que los riesgos de las inversiones se reducen.

\section{PALABRAS CLAVE}

Generación distribuida, Estrategia. Sistema solar fotovoltaica. Energía solar. Factibilidad de inversiones.

\section{REFERENCES}

Agência Nacional de Energia Elétrica (2012). Resolução Normativa n. 482/2012, de 17 de abril de 2012. Retrieved June 13, 2013, from http://www.aneel.gov. br/cedoc/bren2012482.pdf.

Agência Nacional de Energia Elétrica (2014). Banco de informações de geração. Brasília. Retrieved February 20, 2017, from http://www.aneel.gov.br/ informacoes-tecnicas/-/asset_publisher/CegkWaVJWF5E/content/bigbanco-de-informacoes-de-geracao/655808 ? inheritRedirect $=$ false\&redirec $\mathrm{t}=\mathrm{http} \% 3 \mathrm{~A} \% 2 \mathrm{~F} \% 2 \mathrm{Fwww}$.aneel.gov.br\%2Finformacoes-tecnicas\%3Fp_p_ id\%3D101_INSTANCE_CegkWaVJWF5E\%26p_p_lifecycle\%3D0\%26p_p_ state\%3Dnormal\%26p_p_mode\%3Dview\%26p_p_col_id\%3Dcolumn2\%26p_p_col_pos\%3D1\%26p_p_col_count\%3D2.

Agência Nacional de Energia Elétrica (2015). Nota Técnica n. 017/2015-SRD. Proposta de abertura de audiência pública para o recebimento de contribuições visando aprimorar a Resolução Normativa n. 482/2012 e a seção 3.7 do Módulo 3 do PRODIST. Retrieved 14 July, 2015, from <http://www.aneel. gov.br/cedoc/bren2012482.pdf>.

Agência Nacional de Energia Elétrica (2016). Micro e minigeração distribuída: sistema de compensação de energia elétrica (2a ed., 31 p.). Brasília, DF: Aneel. 
América do Sol simulator. Guia de microgeradores fotovoltaicos. Retrieved Dec., 2015, from http://www.americadosol.org/guiaFV/.

Barroso, L. A., Rosenblatt, J., \& Veiga, M. (2015). Setor elétrico brasileiro: estado atual e sugestões. Visões do setor elétrico. São Paulo. Retrieved 12, July, 2015, from http://visoesdosetoreletrico.com.br.

Brasil (2002). Lei n. 10.438, de 26 de abril de 2002. Dispõe sobre a expansão da oferta de energia elétrica emergencial, recomposição tarifária extraordinária, cria o Programa de Incentivo às Fontes Alternativas de Energia Elétrica (Proinfa), a Conta de Desenvolvimento Energético (CDE), dispõe sobre a universalização do serviço público de energia elétrica, dá nova redação às Leis n. 9.427, de 26 de dezembro de 1996, no 9.648, de 27 de maio de 1998, n. 3.890-A, de 25 de abril de 1961, n. 5.655, de 20 de maio de 1971, n. 5.899, de 5 de julho de 1973, n. 9.991, de 24 de julho de 2000, e dá outras providências. Retrieved May 16, 2013, from http://www.planalto.gov.br/ccivil_03/ leis/2002/L10438.htm.

Brasil (2003). Lei n. 10.762, de 11 de novembro de 2003. Dispõe sobre a criação do Programa Emergencial e Excepcional de Apoio às Concessionárias de Serviços Públicos de Distribuição de Energia Elétrica, altera as Leis n. 8.631, de 4 de março de 1993, 9.427, de 26 de dezembro de 1996, n. 10.438, de 26 de abril de 2002, e dá outras providências Retrieved March 22, 2013, from http://www2.camara.leg.br/legin/fed/lei/2003/lei-10762-11-novembro2003-497315-norma-pl.html.

Brasil (2013). Convênio ICMS n. 006/13, de 05 de abril 2013. Estabelece disciplina para fins da emissão de documentos fiscais nas operações internas relativas à circulação de energia elétrica, sujeitas a faturamento sob o Sistema de Compensação de Energia Elétrica de que trata a Resolução Normativa n. 482/2012. Retrieved August 11, 2013, from https://www.confaz.fazenda. gov.br/legislacao/convenios/2013/cv006_13.

Casarotto, F. N. S., \& Kopittke, B. H. (2007). Análise de Investimentos. 10a ed. São Paulo: Editora Atlas.

Ceará (2017). Secretaria da Fazenda do Estado do Ceará. Retrieved February, 2017, from http://www.sefaz.ce.gov.br/Content/aplicacao/internet/legislacao_tributaria.

Centro de Referência para Energia Solar e Eólica Sérgio de Salvo Brito. (2014). Simulador América do Sol. Wind Power, Principles and Applications. Retrieved April 20, 2014, from http://www.cresesb.cepel.br/.

Correia Neto, J. C. (2009). Elaboração e avaliação de projetos de investimento (1a ed.). Rio de Janeiro: Editora Campus. 
Dias, A. C. R. M., Batian-Pinto, C. L. B., Brandão, L. E. T., \& Gomes, L. L. (2011). Flexibility and uncertainty in agribusiness projects: investing in a cogeneration plant. Revista de Administração Mackenzie, 12 (4), jul/ago, 105-126. Empresa de Pesquisa Energética. (2015). Matriz Energética Nacional - 2030. Retrieved August 26, 2015, from https://ben.epe.gov.br/default.aspx?ano Coleta $=2015$.

Ganim, A. (2009). Setor elétrico brasileiro: aspectos regulamentares, tributários e contábeis (2a ed. rev.). Rio de Janeiro: Synergia: Canal Energia.

Giddens, A. (2010). A política da mudança climática (1a ed.). Rio de Janeiro: Zahar. Holdermann, C., Kissel, J., \& Beigel, J. (2014). Distributed photovoltaic generation in Brazil: an economic viability analysis of small-scale photovoltaic systems in the residential and commercial sectors. Energy Police, 67, 612-617.

Jannuzzi, G. M., \& Melo, C. A. (2013). Grid-connected photovoltaic in Brazil: policies and potential impacts for 2030. Energy for Sustainable Development, 17(1), 40-46.

Kyocera Solar do Brasil Ltda. (2017). Retrieved February, 2017, from http:// www.kyocerasolar.com.br/.

Lacchini, C., \& Santos, J. C. V. (2013). Photovoltaic energy generation in Brazil - Cost analysis using coal-fired power plants as comparison. Renewable Energy, $52(\mathrm{C})$, 183-189.

Landau, E. (2008). É preciso aumentar a diversificação da matriz energética brasileira. Revista Opiniões - sobre cogeração e energia elétrica, Retrieved June 13, 2015, from http://raceadmv3.nuca.ie.ufrj.br/buscarace/Docs/elandau4.pdf. Leonelli, P. A., Galdino, M. A. E., Pereira, O. L. S., Rüther, R., \& Zilles, R. (2009). Grupo de trabalho de geração distribuída com sistemas fotovoltaicos - GT-GDSF. Portaria n. 36, de 26 de novembro de 2008. Brasília. DF: Ministério de Minas e Energia.

Lora, E. E. S., \& Haddad, J. (2006). Geração distribuída - aspectos tecnológicos, ambientais e institucionais. Rio de Janeiro: Interciência.

Martins, F. R., Rüther, R., Pereira, E. B., \& Abreu, S. (2008). Solar energy scenarios in Brazil. Part two: Photovoltaics applications. Energy Police, 36(8), 2865-2877.

Ministério de Minas e Energia (2012). Boletim mensal de monitoramento do Sistema Elétrico Brasileiro. Brasília, DF. Retrieved February 16, 2016, from http:// www.mme.gov.br/web/guest/secretarias/energia-eletrica/publicacoes/ boletim-de-monitoramento-do-sistema-eletrico/boletins-2012. 
Ministério de Minas e Energia. (2015). Boletim Mensal de Monitoramento do Sistema Elétrico Brasileiro. Brasilia, DF. Retrieved February 17, 2015, from http:// www.mme.gov.br/web/guest/secretarias/energia-eletrica/publicacoes/boletim-de-monitoramento-do-sistema-eletrico/boletins-2015.

Nascimento, L. R., \& Rüther, R. (2014). Avaliação de longo prazo de um sistema fotovoltaico integrado à edificação urbana e conectado à rede elétrica pública. Revista Brasileira de Energia Solar, V(1), 73-81.

Pereira, J. A. O., Pereira, A. S., La Rovere, E. L., Barata, M. M. L., Villar, S. C., \& Pires, S. H. (2011). Strategies to promote renewable energy in Brazil. Renewable and Sustainable Energy Reviews, 15(1), 681-688.

Rodriguez, C. R. C., \& Jannuzzi, G. M. (2002). Mecanismos regulatórios, tarifários e econômicos na geração distribuída: $O$ caso dos sistemas fotovoltaicos conectados à rede. Dissertação de mestrado, Universidade Estadual de Campinas, Campinas, SP, Brasil.

Rubert, T., Schwardt, M., \& Abreu, M. C. S. (2014). A comparative analysis of the development of renewable energy in Brazil and Germany. Latin American Journal Management for Sustainable Development, 1(2/3), 146-163.

Rüther, R. (2008). Potential building of integrated photovoltaic solar energy generators in assisting daytime peaking feeders in urban area in Brazil. Energy Conservation and Management, 49(5), 1074-1079.

Sun Solutions (2014). Soluções em energia solar fotovoltaica. Retrieved 28 April, 2014, from www.sunsolutions.com.br.

Viana, T. S., Rüther, R., Martins, F. R., \& Pereira, E. B. (2011). Assessing the potential of concentrating solar photovoltaic generation in Brazil with satellite-derived direct normal irradiation. Sciencedirect. Solar Energy, 85(3), 486-495.

Watts, D., Váldés, M. F., Jara, D., \& Watson, A. (2015). Potential residential PV development in Chile: the effect of net metering and net billing schemes for grid-connected PV systems. Renewable and Sustainable Energy Reviews, 41 (C), 1037-1051. 